Published in final edited form as:

Clin Pharmacol Ther. 2008 December ; 84(6): 734-740. doi:10.1038/clpt.2008.187.

\title{
Personalized Therapeutics: HIV Treatment in Adolescents
}

\author{
NY Rakhmanina ${ }^{1,2}$, EV Capparelli ${ }^{3,4}$, and JN van den Anker ${ }^{2,5}$ \\ ${ }^{1}$ Division of Infectious Disease, Children's National Medical Center/George Washington \\ University School of Medicine and Health Sciences, Washington, DC, USA \\ 2Division of Pediatric Clinical Pharmacology, Department of Pediatrics, Children's National \\ Medical Center/George Washington University School of Medicine and Health Sciences, \\ Washington, DC, USA
}

${ }^{3}$ Division of Pediatric Clinical Pharmacology and Developmental Therapeutics, Department of Pediatrics, University of California San Diego, La Jolla, California, USA

${ }^{4}$ Skaggs School of Pharmacy, University of California San Diego, La Jolla, California, USA

${ }^{5}$ Department of Pharmacology and Physiology, Children's National Medical Center/George Washington University School of Medicine and Health Sciences, Washington, DC, USA.

\section{Abstract}

Adolescents infected with human immunodeficiency virus (HIV) represent a heterogeneous group of pubertal children and young adults. Antiretroviral therapy (ART) in adolescents is complex and depends on multiple factors. The continued use of higher (weight- or surface-based) pediatric doses can result in potentially toxic drug exposure, whereas early introduction of lower adult doses can lead to the development of drug resistance and virologic failure. The physiological and psychosocial changes during puberty create strong grounds for an individualized therapeutic approach in HIV-infected adolescents.

\begin{abstract}
Despite significant progress in the prevention of mother-to-child transmission of human immunodeficiency virus (HIV) infection, it was estimated that there were 2.3 million children under the age of 15 years with HIV infection in 2006.1 Among those, 780,000 $(600,000-1,000,000)$ were estimated to be in need of antiretroviral therapy (ART). In the United States and other developed countries, an increasing number of children with perinatally acquired HIV infection are now surviving into adolescence and adulthood. In addition, large numbers of American teenagers continue to acquire HIV infection through sexual contact and intravenous drug use; youths between 13 and 24 years of age account for $15 \%$ of the 40,000 new HIV cases per year.2 Based on the strengthening global response to the problem of HIV/AIDS in recent years, the number of adolescents receiving ART worldwide is rapidly increasing. 3 Given the growing number of HIV-infected youth with access to ART, a better understanding of the disposition of antiretroviral (ARV) drugs during puberty is urgently needed. The selection of ART dosages for patients in the pubertal stages of maximal growth is left to the provider's discretion, and individual differences in the progression to sexual maturation are often not provided for. The recently published report by the Committee on Pediatric AIDS, dealing with increasing access to antiretroviral
\end{abstract}

(C) 2008 American Society for Clinical Pharmacology and Therapeutics

Correspondence: NY Rakhmanina (nrakhman@cnmc.org).

CONFLICT OF INTEREST

E.V.C. is a DSMB Member of Pfizer Pharmaceuticals and a consultant for GlaxoSmithKline. The other authors declared no conflict of interest. 
(ARV) drugs for pediatric patients, identifies the lack of appropriate dosing of ARV drugs in adolescents as one of the barriers to providing ART to HIV-infected children and youth globally.3 The report underlines that, even with the availability of appropriate ART, the pharmacokinetic (PK) data may be insufficient to appropriately guide the dosing in adolescent patients, who may need higher than "maximum adult dose" to ensure adequate drug exposure.3,4 Consequently, adolescents are identified as a separate study cohort when investigating the PK and pharmacodynamics (PD) of ARV agents in children, and the need for phase II and III studies in this cohort is underscored.

Several pediatric HIV research networks (Pediatric AIDS Clinical Trials Group (PACTG)/ HIV Prevention Trials Network/International Maternal Pediatric Adolescent AIDS Clinical Trials, Collaborative HIV Pediatric Study, Pediatric European Network for Treatment of AIDS, the HIV Netherlands Australia Thailand Research Collaboration, and Adolescent Medicine Trials Network) have addressed issues of developmental PK/PD of ART in HIVinfected pediatric patients. However, very few studies have investigated the PK/PD of ARV agents in adolescents and young adults. The PK of abacavir were reported from the PACTG protocols P1018 and P1052;5,6 lamivudine and zidovudine data (including data on phosphorylation to the intracellular triphosphate metabolites) were collected in PACTG studies P1012 and P1052;7 lopinavir/ritonavir and saquinavir were studied in PACTG protocol P1038;8 and atazanavir was studied in PACTG protocol 1020A and in Adolescent Medicine Trials Network studies along with tenofovir.5'9 The PACTG protocol P1038 and the author's study in children with experience of ARV suggested that the use of high doses of lopinavir/ritonavir might be required for salvage HIV therapy in adolescent patients. 8,10 The Adolescent Medicine Trials Network study by Kiser et al. evaluated the PK of the combined administration of atazanavir/ritonavir and tenofovir in young adults with HIV infection.9 A higher level of tenofovir exposure was expected on the basis of data from healthy volunteers, but this was not seen in HIV-infected subjects, most likely because of a faster tenofovir clearance, as apparent in the higher creatinine clearances observed in this age group.9 None of the available studies in adolescents has investigated the effects of pubertal changes on the required dosage in ART, and information on failed ART or increased drug resistance in HIV-infected adolescents is very limited. No studies have addressed the important issue of the long-term effects of ART exposure during puberty. Such possible effects include ART-associated hyperlipidemia and a risk of developing cardiovascular disease. Finally, adolescent patients are frequently exposed to antidepressants, hormonal contraceptives, anabolic steroids, alcohol, and illicit drugs. No studies are available to date on the effects of psychotropic drugs, substance abuse, and exogenous sex hormones on ART drug disposition and efficacy in adolescence, although there is an abundance of pharmacological data pertaining to the adult population.

HIV-infected adolescents represent a heterogeneous group of pubertal children and young adults at different stages of psychosocial development, with vertically and horizontally transmitted HIV infection, varying demographic and socioeconomic statuses, and diverse histories of sexual and substance abuse. The choice of ART regimen must balance many of these factors in addition to the selection of the correct dosage of ARV drugs. Clinicians are faced with the dilemma of choosing a dosing regimen that falls somewhere between pediatric (weight- and surface-based) and adult (fixed-dose) guidelines. The World Health Organization guidelines and the US guidelines for ART in adolescent patients include adolescents within both categories: "pediatric" (infants and children) and "adults and adolescents." The World Health Organization defines the "adolescent" cohort as children aged between 10 and 19 years; the US guidelines use 12 years of age as the cutoff for transition to adolescence.5'11 (Table 1) The appropriate dosing of ARV medications in adolescents is complex and depends on multiple factors, including developmental changes throughout puberty. Although current pediatric HIV treatment guidelines for older children 
recommend considering Tanner stages of puberty when prescribing ART, they do not provide data justifying those recommendations. For children in early puberty (Tanner stages I and II), the US guidelines recommended using pediatric schedules, whereas for adolescents in their growth spurt (Tanner stages III and IV), both adult and pediatric dosing schedules are recommended.5 The World Health Organization pediatric guidelines extend pediatric dosing to Tanner stage III and recommend adult dosing in adolescents in Tanner stages IV and V.11 Both guidelines recommend considering issues such as toxicity, adherence, and virologic and immunologic parameters when determining the timing of transition from pediatric to adult doses. The continued use of higher (weight- or surface-based) pediatric doses during adolescence can result in increased and potentially toxic drug exposure, whereas early introduction of lower adult doses can lead to suboptimal therapeutic exposure and development of drug resistance and subsequent virologic failure.

Few studies have addressed the effect of HIV infection and ART on puberty, and these were conducted in adolescents with perinatally acquired HIV infection in the era of limited therapeutic choices.12,13 The study by De Martino et al. reported a delay in the onset of puberty in Caucasian HIV-infected children independent of clinical or immunological status. 12 A much larger prospective cohort study from the United States, carried out by the PACTG 219 Study Team among children of diverse ethnic and racial backgrounds, reported a direct association between immunosuppression and a delayed onset of puberty.13 This study, however, simplified the classification of Tanner stages and did not record orchidometric data. This omission could lead to a potential misclassification of the Tanner stage. Recently, a much smaller longitudinal study of $10 \mathrm{HIV}$-infected children, involving a thorough puberty evaluation including serial quantitations of plasma growth hormones (GHs), gonadotropins, and sex steroids, has demonstrated that children with a good control of HIV infection showed growth and pubertal development within the physiological percentile for their age.14 Further studies are necessary to understand the impact of perinatally and behaviorally acquired HIV infection and ART on the onset and progression of puberty.

Puberty is characterized by an increase in growth velocity, changes in body composition, and the appearance of striking somatic changes. The changes in body composition vary between the sexes, with a significant increase in lean body mass in boys and an accumulation of fat in girls.15,16 Girls are generally a year or two more advanced in pubertal maturation than boys, and the African-American race has been associated with an earlier onset of menarche.16'17 Peak height velocity in girls occurs before menarche (which in turn takes place $\sim 2-2.5$ years after the first signs of breast development), whereas significant changes in genital development usually precede peak height velocity in boys. 18 In each gender, it takes about 4.5 years (3-6 years) from the first appearance of secondary sex characteristics to adult body configuration. Significant hormonal changes occur during adrenarche just prior to the appearance of secondary sexual characteristics, and gonadotropins, sex steroids, and GHs show different secretory patterns during different pubertal stages in boys and girls. The increase in circulating GH and insulin-like GH (IGF-1) levels is seen in girls at Tanner stage II (Breast II), whereas in boys it is usually delayed until stages II to III (Genital II-III).19 In boys, rapidly rising testosterone levels cause an increase in GH/IGF-1 secretion and growth velocity. In girls, mean plasma levels of estradiol have been shown to rise steadily throughout puberty, with wide individual fluctuations depending on the time relative to menarche and the ovulatory cycle.19 A careful history and thorough physical examination by an experienced provider is required for accurately evaluating the onset and progress of puberty.

To date, little attention has been paid to the developmental processes of puberty, and drug PK/PD data in the adolescent population are remarkably limited.20 The concept of 
adolescent developmental pharmacology was proposed by Hein in 1987.21 Since then, few PK studies have been published in this field.22-24 Changes in the effects of ABCB1 polymorphisms on the bioavailability of oral cyclosporine have been shown to occur in pediatric renal transplant patients $>8$ years of age as compared to younger children.24 The sexual maturation rate was shown to affect the net renal tubular secretion of digoxin. 25 Tanner stage and presence of sex steroids were shown to affect the clearance of antipyrine. 22 Puberty has also been shown to affect the activity of selected CYP450 isoforms. Using a caffeine breath test, Lambert et al. demonstrated an association between Tanner stage and age-dependent inducibility of the CYP1A2 pathway.23 The correlation with Tanner stage appeared to be sex-dependent, with a decrease in clearance seen at an earlier Tanner stage in girls than in boys. Similar data on sex-associated differences were observed in studies on theophylline metabolism in adolescents.26 A recent study by Saitoh et al. on the effect of CYP2B6 on efavirenz PK in HIV-infected children has demonstrated that age and CYP2B6 G516T genotype were independently and statistically associated with efavirenz clearance.27 These results suggest that age-related changes in CYP2B6 activity may need to be considered when evaluating the impact of genetic variants on efavirenz PK in children. Developmental changes in CYP450 activity have the potential to affect disposition and clearance of non-nucleoside reverse transcriptase inhibitors and protease inhibitors during puberty and may produce new models of drug-drug interactions with CYP450 substrates, inducers, and suppressors such as those used in concomitant ARV and antimycobacterial therapy.

A high level of patient adherence to the regimen is required to achieve a successful outcome for ART.28 It must be recognized that HIV-infected adolescents face multiple challenges in fulfilling the adherence requirements because of the dynamic period of transition from childhood to adulthood. In addition to the well-recognized pediatric adherence barriers such as dependence on a caregiver for obtaining medications, palatability, pill burden, and interference with lifestyle, many obstacles to adherence emerge in adolescence, and these are related to the psychosocial changes during puberty. Among these are changes in lifestyle involving growing independence and rebellion against parental involvement, increased peer pressure and fear of stigmatization, increased risk-taking behavior, denial and fear of HIV infection (particularly in recently diagnosed youth), long history of poor adherence and nondisclosure issues in perinatally infected adolescents, psychiatric problems (depression), and alcohol and substance abuse.29,30 A comprehensive assessment of adherence through multiple methods (such as self-report, pill count, pharmacy refills, and therapeutic drug monitoring) should be incorporated into the ART of every adolescent HIV patient. Although strategies to promote long-term adherence to ART have not been rigorously evaluated in adolescents to date, preliminary data suggest that interventions based on intensive follow-up, involvement of family and peers, use of reminder systems, alternative dosing schedules, and directly observed therapy may facilitate adherence to the dosing regimen in this vulnerable population. 30

The developmental physiological, psychological, and social changes during puberty create strong grounds for an individualized therapeutic approach to HIV-infected adolescents. The concept of developmental rather than chronological age needs to be considered in adolescents. As the use of ART continues to expand among an aging cohort of HIV-infected children and newly infected adolescents, large collaborative studies are urgently needed to evaluate ARV drug exposure in adolescents, and accurate growth curves and sexual maturation staging of HIV-infected children and adolescents of various ethnic and racial backgrounds need to be developed. Finally, better adherence interventions and simplified ART regimens with newer ARV agents are needed to improve the outcome of therapy in HIV-infected adolescents. 


\section{Acknowledgments}

The clinical research of the authors is supported by the Department of Health and Human Services, National Institutes of Health Public Health Service grants NCRR 1K12 RR017613, NICHD 5U10 HD031318, NICHD 1 U10 HD45993, and NCRR 1K24RR019729.

\section{References}

1. UNAIDS. AIDS epidemic update: December 2007. 2008 [Accessed 11 June 2008]. <http://data.unaids.org/pub/EPISlides/2007/2007_epiupdate_en.pdf>

2. CDC. HIV/AIDS Surveillance Report. 2006. Atlanta: US Department of Health and Human Services; 2008.

3. Havens PL, Gibb DM. American Academy of Pediatrics Committee on Pediatric AIDS, Section on International Child Health. Increasing antiretroviral drug access for children with HIV infection. Pediatrics. 2007; 119:838-845. [PubMed: 17403860]

4. Grub S, et al. Pharmacokinetics and pharmacodynamics of saquinavir in pediatric patients with human immunodeficiency virus infection. Clin. Pharmacol. Ther. 2002; 71:122-130. [PubMed: 11907486]

5. Department of Health and Human Services. Guidelines for the use of antiretroviral agents in pediatric HIV infection. 2008 [Accessed 27 June 2008]. <http://aidsinfo.nih.gov/contentfiles/PediatricGuidelines.pdf>

6. Rodman, JH., et al. Abacavir systemic clearance in children is highly influenced by glucuronidation phenotype. 14th International AIDS Conference; 5-12 July 2002; Barcelona, Spain. Abstract MoPpB2010.

7. Flynn PM, et al. Intracellular pharmacokinetics of once versus twice daily zidovudine and lamivudine in adolescents. Antimicrob. Agents Chemother. 2007; 51:3516-3522. [PubMed: 17664328]

8. Robbins BL, et al. Pharmacokinetics of high-dose lopinavir-ritonavir with and without saquinavir or nonnucleoside reverse transcriptase inhibitors in HIV infected pediatric and adolescent patients previously treated with protease inhibitors. Antimicrob. Agents Chemother. 2008; 52:3276-3283. [PubMed: 18625762]

9. Kiser JJ, et al. Pharmacokinetics of antiretroviral regimens containing tenofovir disoproxil fumarate and atazanavir-ritonavir in adolescents and young adults with human immunodeficiency virus infection. Antimicrob. Agents Chemother. 2008; 52:631-637. [PubMed: 18025112]

10. Rakhmanina, N., et al. Recommended dose of lopinavir/ritonavir is suboptimal in protease inhibitor-experienced children. 15th Conference on Retroviruses and Opportunistic Infections; 3-6 February 2008; Boston, MA. Abstract 574.

11. WHO. Antiretroviral therapy for HIV infection in infants and children: towards universal access. 2006 [Accessed 23 June 2008]. 〈http://www.who.int/hiv/pub/guidelines/paediatric020907.pdf>

12. de Martino M, et al. Puberty in perinatal HIV-1 infection: a multicentre longitudinal study of 212 children. AIDS. 2001; 15:1527-1534. [PubMed: 11504985]

13. Buchacz K, et al. Delayed onset of pubertal development in children and adolescents with perinatally acquired HIV infection. J. Acquir. Immune Defic. Syndr. 2003; 33:56-65. [PubMed: 12792356]

14. Titone L, et al. Hormonal, auxological and clinical follow-up in children with connatal HIV infection. Personal records. Minerva Pediatr. 2006; 58:461-467. [PubMed: 17008857]

15. Kreipe, R. Normal somatic adolescent growth and development. In: McAnarney, ER., et al., editors. Textbook of Adolescent Medicine. Vol. 57. Philadelphia, PA: WB Saunders; 1992.

16. Tanner, J. Growth at Adolescence. London, England: Blackwell Scientific; 1962.

17. National Center for Health Statistics: Age at menarche, US. 1973; 133(11):2-3.

18. Abbassi V. Growth and normal puberty. Pediatrics. 1998; 102(2 Pt 3):507-511. [PubMed: 9685454] 
19. Albertsson-Wikland K, Rosberg S, Karlberg J, Groth T. Analysis of 24-hour growth hormone profiles in healthy boys and girls of normal stature: relation to puberty. J. Clin. Endocrinol. Metab. 1994; 78:1195-1201. [PubMed: 8175978]

20. Rogers A. A. Pharmacokinetics and pharmacodynamics in adolescents. January 20-21, 1994. Proceedings. J. Adolesc. Health. 1994; 15:605-678. [PubMed: 7696278]

21. Hein K. Developmental pharmacology in adolescence. The inauguration of a new field. J. Adolesc. Health Care. 1987; 8:1-4. [PubMed: 3818402]

22. Linday LA, et al. Changes in salivary antipyrine pharmacokinetics during adolescence, correlated with age, hormonal levels and Tanner stage. Dev. Pharmacol. Ther. 1991; 16:194-202. [PubMed: 1782837]

23. Lambert GH, Schoeller DA, Kotake AN, Flores C, Hay D. The effect of age, gender, and sexual maturation on the caffeine breath test. Dev. Pharmacol. Ther. 1986; 9:375-388. [PubMed: 3102191]

24. Fanta S, et al. Pharmacogenetics of cyclosporine in children suggests an age-dependent influence of ABCB1 polymorphisms. Pharmacogenet. Genomics. 2008; 18:77-90. [PubMed: 18192894]

25. Linday LA, Drayer DE, Khan MA, Cicalese C, Reidenberg MM. Pubertal changes in net renal tubular secretion of digoxin. Clin. Pharmacol. Ther. 1984; 35:438-446. [PubMed: 6368090]

26. Cary J, Hein K, Dell R. Theophylline disposition in adolescents with asthma. Ther. Drug Monit. 1991; 13:309-313. [PubMed: 1780962]

27. Saitoh A, et al. Efavirenz pharmacokinetics in HIV-1-infected children are associated with CYP2B6-G516T polymorphism. J. Acquir. Immune Defic. Syndr. 2007; 45:280-285. [PubMed: 17356468]

28. Williams PL, et al. Predictors of adherence to antiretroviral medications in children and adolescents with HIV infection. Pediatrics. 2006; 118:e1745-e1757. [PubMed: 17101712]

29. Murphy DA, Wilson CM, Durako SJ, Muenz LR, Belzer M. Adolescent Medicine HIV/AIDS Research Network. Antiretroviral medication adherence among the REACH HIV-infected adolescent cohort in the USA. AIDS Care. 2001; 13:27-40. [PubMed: 11177463]

30. Simoni JM, Montgomery A, Martin E, New M, Demas PA, Rana S. Adherence to antiretroviral therapy for pediatric HIV infection: a qualitative systematic review with recommendations for research and clinical management. Pediatrics. 2007; 119:e1371-e1383. [PubMed: 17533177] 
Table 1

Recommended doses of antiretroviral medications in adolescent ${ }^{a}$ patients according to WHO and US guidelines $^{b}$

\begin{tabular}{|c|c|c|}
\hline Drug & WHO guidelines & US guidelines \\
\hline $\begin{array}{l}\text { Abacavir } \\
\left(\text { ABC }, \text { Ziagen }{ }^{\circledR}\right)\end{array}$ & $\begin{array}{l}\text { Children }<16 \text { years or body weight }<37.5 \\
\mathrm{~kg}-8 \mathrm{mg} / \\
\mathrm{kg} / \mathrm{dose} \text { twice daily. } \\
\text { Maximal dose }->16 \text { years or } 237.5 \mathrm{~kg}- \\
300 \mathrm{mg} / \mathrm{dose} \\
\text { twice daily. } \\
\text { Once daily dosing is not yet approved in } \\
\text { children but } \\
\text { encouraging PK data is available. } \\
\text { Adults-300 mg/dose twice daily or } 600 \\
\text { mg once daily. } \\
\text { Combination ART: } \\
\quad 300 \mathrm{mg} \mathrm{AZT} / 150 \mathrm{mg} 3 \mathrm{TC} / 300 \\
\quad \text { mg ABC- }-1 / \text { dose twice daily. }\end{array}$ & 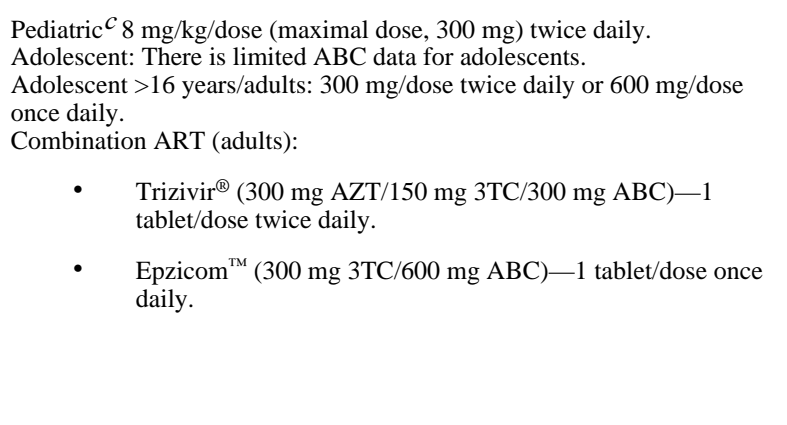 \\
\hline $\begin{array}{l}\text { Didanosine } \\
\text { (dideoxinosine, } \\
\text { ddI, Videx }^{\circledR} \text { ) }\end{array}$ & $\begin{array}{l}\text { Children }<13 \text { years of age }-90-120 \mathrm{mg} / \mathrm{m}^{2} / \\
\text { dose } \\
\text { twice daily. Maximal dose->16 years or } \\
\text { body weight } \\
>60 \mathrm{~kg}-200 \mathrm{mg} / \text { dose twice daily or } 400 \\
\mathrm{mg} / \mathrm{dose} \\
\text { once daily (enteric coated (EC)). Once daily } \\
\text { dosing for } \\
\text { chewable tablets is authorized in the United } \\
\text { Kingdom } \\
\text { for children }>6 \text { years of age. } \\
\text { Adults-body weight }>60 \mathrm{~kg}-400 \mathrm{mg} \\
\text { once daily, } \\
\text { body weight }<60 \mathrm{~kg}-250 \mathrm{mg} \text { once daily. }\end{array}$ & $\begin{array}{l}\text { Pediatric: } 90-150 \mathrm{mg} / \mathrm{m}^{2} / \text { dose twice daily (average dose } 120 \mathrm{mg} / \mathrm{m}^{2} \text { ) or in } \\
\text { treatment-naive patients } 3-21 \text { years of age } 240 \mathrm{mg} / \mathrm{m}^{2} / \text { dose once daily. } \\
\text { Adolescent/adults: oral solution-body weight }>60 \mathrm{~kg}-200 \mathrm{mg} / \mathrm{dose} \\
\text { twice } \\
\text { daily or } 250 \mathrm{mg} / \mathrm{dose} \text {, if co-administered with TDF. } \\
\text { Body weight }<60 \mathrm{~kg}-125 \mathrm{mg} / \text { dose twice daily. The total daily dose may } \\
\text { be } \\
\text { administered once daily, twice daily dosing is preferred. }\end{array}$ \\
\hline $\begin{array}{l}\text { Emtricitabine } \\
\left(\text { FTC, Emtriva }{ }^{\mathrm{TM}}\right)\end{array}$ & $\begin{array}{l}\text { No dosing guidelines for children. } \\
\text { Adults }-200 \mathrm{mg} / \text { dose once daily. }\end{array}$ & 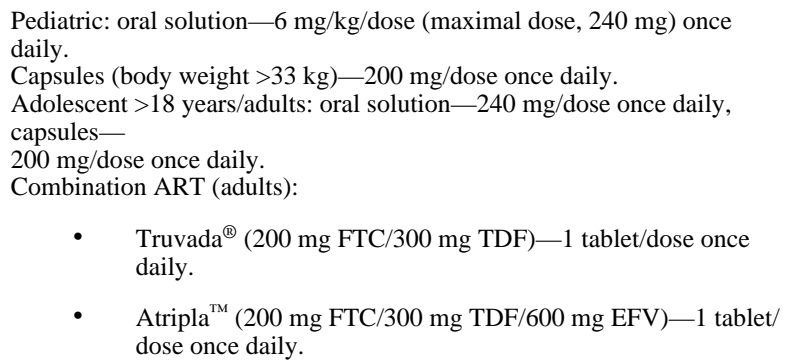 \\
\hline $\begin{array}{l}\text { Lamivudine } \\
\left(3 \mathrm{TC}, \text { Epivir }^{\circledR} \text {, }\right. \\
\text { Epivir HBV) }\end{array}$ & 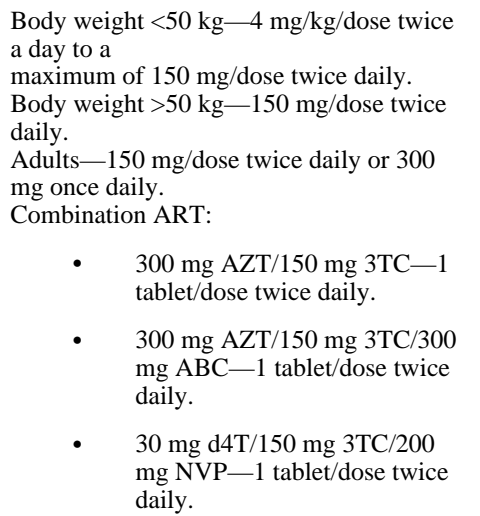 & 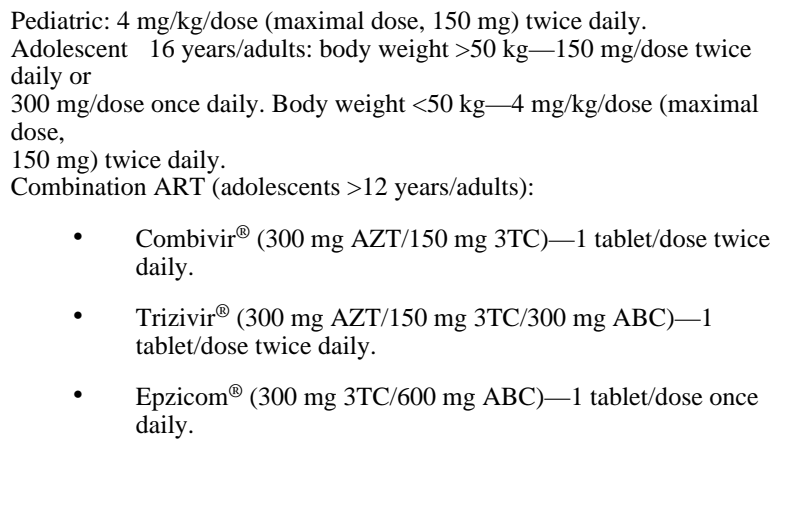 \\
\hline
\end{tabular}




\begin{tabular}{|c|c|c|}
\hline Drug & WHO guidelines & US guidelines \\
\hline $\begin{array}{l}\text { Stavudine } \\
\left(\mathrm{d} 4 \mathrm{~T}, \text { Zerit }^{\circledR}\right)\end{array}$ & 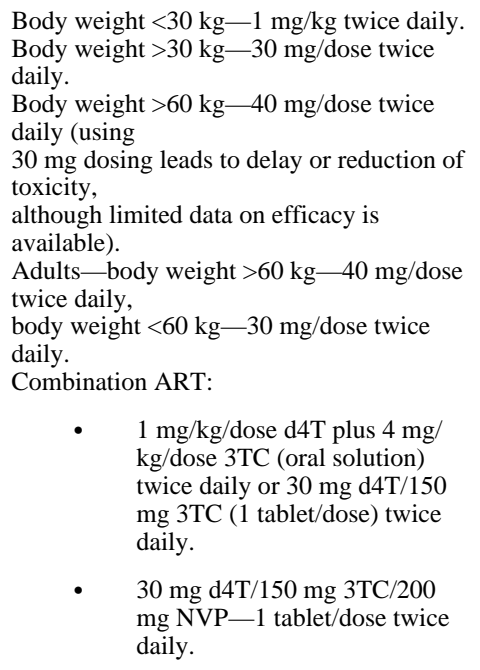 & $\begin{array}{l}\text { Pediatric: body weight }<30 \mathrm{~kg}-1 \mathrm{mg} / \mathrm{kg} / \mathrm{dose} \text { twice daily. } \\
\text { Adolescent (body weight } 230 \mathrm{~kg} \text { )/adults: body weight } 30-<60 \mathrm{~kg}-30 \\
\text { mg/dose } \\
\text { twice a day. } \\
\text { Body weight } \succeq 60 \mathrm{~kg}-40 \mathrm{mg} / \mathrm{dose} \text { twice daily. }\end{array}$ \\
\hline $\begin{array}{l}\text { Tenofovir } \\
\left(\text { TDF, Viread }{ }^{\circledR}\right)\end{array}$ & $\begin{array}{l}\text { No dosing guidelines for children. } \\
\text { Adults_-300 mg once daily. }\end{array}$ & $\begin{array}{l}\text { Pediatric: investigational dose-210 mg/m²/dose (maximal dose, } 300 \mathrm{mg} \text { ) } \\
\text { once daily. } \\
\text { Adolescent > } 18 \text { years/adults: } 300 \mathrm{mg} / \mathrm{dose} \text { once daily. } \\
\text { Combination ART (adults): } \\
\qquad \quad \text { Truvada }^{\circledR}(200 \mathrm{mg} \mathrm{FTC} / 300 \mathrm{mg} \text { TDF) }-1 \text { tablet/dose once } \\
\text { daily. } \\
\text { - } \text { Atripla }^{\mathrm{TM}}(200 \mathrm{mg} \mathrm{FTC} / 300 \mathrm{mg} \text { TDF} / 600 \mathrm{mg} \mathrm{EFV})-1 \text { tablet/ } \\
\text { dose once daily. }\end{array}$ \\
\hline $\begin{array}{l}\text { Zidovudine } \\
\text { (ZDV, AZT, } \\
\left.\text { Retrovir }^{\circledR}\right)\end{array}$ & 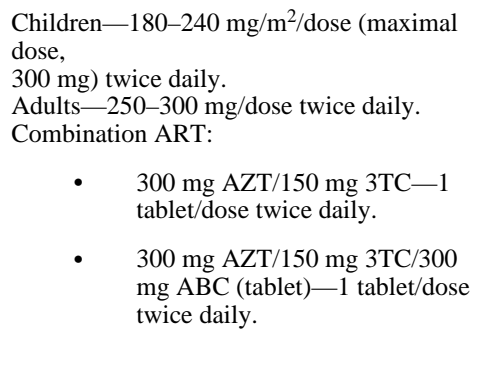 & $\begin{array}{l}\text { Pediatric: } 160 \mathrm{mg} / \mathrm{m}^{2} / \text { dose every } 8 \text { hours (three times daily) or } 180-240 \\
\mathrm{mg} / \\
\mathrm{m}^{2} / \text { dose twice daily. } \\
\text { Adolescent } \geq 12 \text { years/adults: } 200 \mathrm{mg} / \text { dose three times daily or } 300 \mathrm{mg} / \\
\text { dose } \\
\text { twice daily. } \\
\text { Combination ART (adolescent/adults): } \\
\qquad \quad \text { Combivir }{ }^{\circledR}(300 \mathrm{mg} \mathrm{AZT} / 150 \mathrm{mg} 3 \mathrm{TC})-1 \text { tablet/dose once } \\
\text { daily. } \\
\quad \text { Trizivir }{ }^{\circledR}(300 \mathrm{mg} \text { AZT/150 } \mathrm{mg} 3 \mathrm{TC} / 300 \mathrm{mg} \mathrm{ABC})-1 \\
\text { tablet/dose once daily. }\end{array}$ \\
\hline $\begin{array}{l}\text { Efavirenz } \\
(\mathrm{DMP}-266 \mathrm{EFV} \text {, } \\
\text { Sustiva }^{\mathrm{TM}} \text { ) }\end{array}$ & $\begin{array}{l}\text { Body weight }<40 \mathrm{~kg}-19.5 \mathrm{mg} / \mathrm{kg} / \text { day } \\
\text { (syrup) or } \\
15 \mathrm{mg} / \mathrm{kg} / \text { day (capsule/tablet). } \\
\text { Body weight }>40 \mathrm{~kg}-600 \mathrm{mg} / \text { dose once } \\
\text { daily. }\end{array}$ & 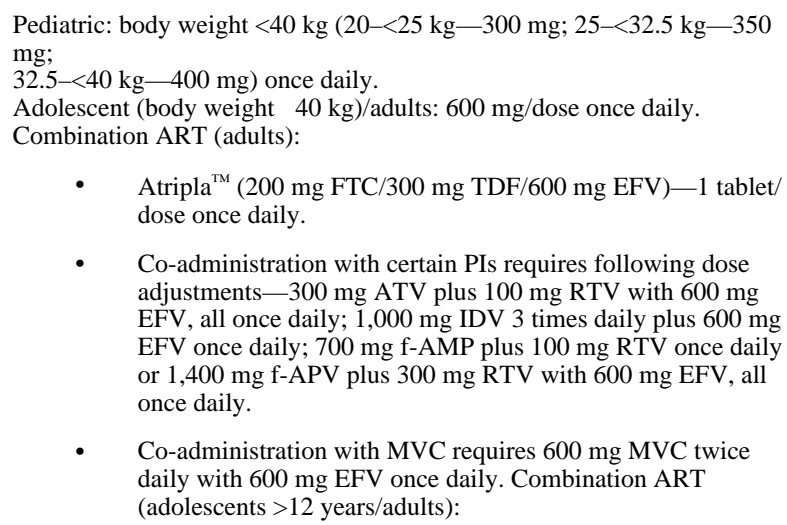 \\
\hline
\end{tabular}

Clin Pharmacol Ther. Author manuscript; available in PMC 2010 January 7. 


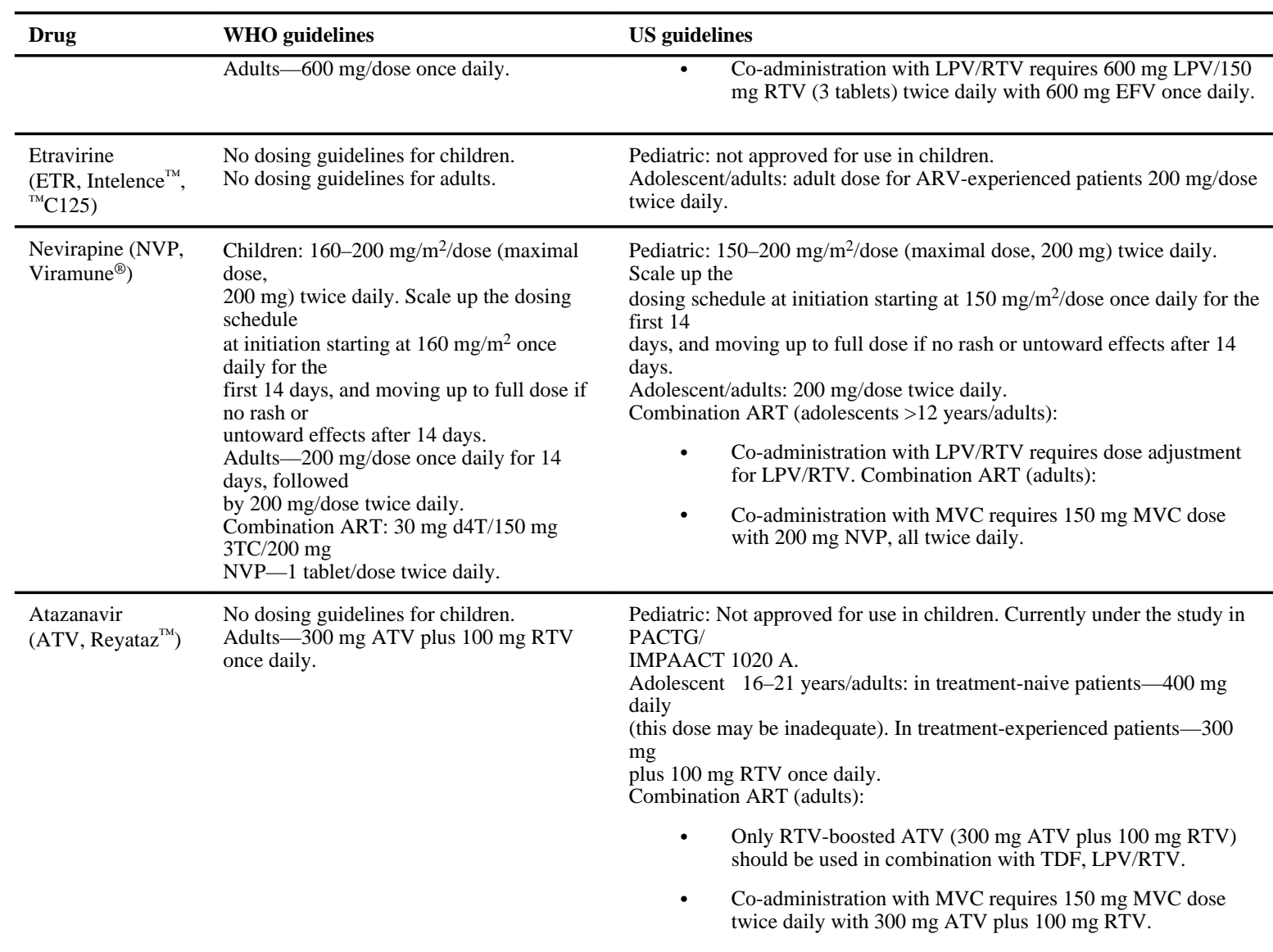

\begin{tabular}{ll}
\hline Darunavir (DRV, & No dosing guidelines for children. \\
${ }^{\mathrm{TM}} \mathrm{C} 114$, Prezista & No dosing guidelines for adults.
\end{tabular}

Pediatric: Not approved for use in children $<18$ years. Currently under the study in PACTG/IMPAACT $1020 \mathrm{~A}$.

${ }^{\mathrm{TM}} \mathrm{C} 114$, Prezista $\left.{ }^{\circledR}\right) \quad$ No dosing guidelines for adults.

Adolescent $\geq 18$ years/adults: $600 \mathrm{mg} /$ dose DRV plus $100 \mathrm{mg}$ RTV twice daily.

DRV should not be used without RTV.

Combination ART (adults):

- Co-administration with MVC requires $150 \mathrm{mg}$ MVC dose DRV $600 \mathrm{mg}$ plus $100 \mathrm{mg}$ RTV, all twice daily.

$\begin{array}{ll}\begin{array}{l}\text { Fosamprenavir } \\ \text { (f-AMP, Lexiva }^{\mathrm{TM}} \text { ) }\end{array} & \begin{array}{l}\text { No dosing guidelines for children. } \\ \text { Adults-700 mg f-AMP plus } 100 \mathrm{mg} \text { RTV } \\ \text { twice daily. }\end{array}\end{array}$

Pediatric $>6$ and $<18$ years: in treatment-naive patients- $30 \mathrm{mg} / \mathrm{kg} / \mathrm{dose}$ (maximal dose, $1,400 \mathrm{mg}$, can be used in patients with body weight $\geq 47$ $\mathrm{kg}$ ) twice daily without RTV or $18 \mathrm{mg} / \mathrm{kg} / \mathrm{dose}$ (maximal dose, $700 \mathrm{mg}$, can be used in patients with body weight $239 \mathrm{~kg}$ ) plus RTV $3 \mathrm{mg} / \mathrm{kg} / \mathrm{dose}$ (maximal

dose, $100 \mathrm{mg}$ ) twice daily (can be used in patients with body weight $\geq 33$ $\mathrm{kg})$.

In treatment-experienced patients- $18 \mathrm{mg} / \mathrm{kg} / \mathrm{dose}$ (maximal dose, 700 mg,

can be used in patients with body weight $239 \mathrm{~kg}$ ) plus RTV $3 \mathrm{mg} / \mathrm{kg} / \mathrm{dose}$ (maximal dose, $100 \mathrm{mg}$, can be used in patients with body weight $233 \mathrm{~kg}$ ) twice daily.

Adults $d$ : in treatment-naive patients $-1,400 \mathrm{mg} /$ dose twice daily without RTV or $700 \mathrm{mg}$ plus $100 \mathrm{mg}$ RTV both twice daily or $1,400 \mathrm{mg}$ plus 200 $\mathrm{mg}$

RTV or $100 \mathrm{mg}$ RTV both given once daily. In treatment-experienced patients $-700 \mathrm{mg}$ plus $100 \mathrm{mg}$ RTV twice daily. Only boosted f-AMP with

RTV should be used in treatment-experienced patients.

Combination ART (adults): 


\begin{tabular}{|c|c|c|}
\hline Drug & WHO guidelines & US guidelines \\
\hline & & $\begin{array}{l}\text { Co-administration with EFV requires f-AMP dose of } 700 \mathrm{mg} \\
\text { plus } 100 \mathrm{mg} \text { RTV twice daily or } 1,400 \mathrm{mg} \text { f-AMP plus } 300 \\
\text { mg RTV once daily. }\end{array}$ \\
\hline & & $\begin{array}{l}\text { - Only boosted f-AMP should be used in combination with } \\
\text { EFV. }\end{array}$ \\
\hline & & $\begin{array}{l}\text { Co-administration with MVC requires } 150 \mathrm{mg} \text { MVC dose } \\
\text { twice daily in combination with } 700 \mathrm{mg} \text { f-AMP plus } 100 \mathrm{mg} \\
\text { RTV twice daily. }\end{array}$ \\
\hline
\end{tabular}

\begin{tabular}{ll}
\hline Indinavir & No dosing guidelines for children. Adults- \\
$($ IDV, Crixivan & $\left.{ }^{\circledR}\right)$ \\
& IDV plus $100 \mathrm{mg}$ RTV twice daily.
\end{tabular}

Pediatric: Not approved for use in children. Investigational dose of $500 \mathrm{mg} / \mathrm{m}^{2}$ of body surface area every 8 hours (three times daily) in children 4-15 years of age resulted in adequate AUC and low plasma IDV trough.

Adolescent $>18$ years/adults: $800 \mathrm{mg} /$ dose every 8 hours. Adult dose in combination with RTV - $800 \mathrm{mg}$ IDV plus $100 \mathrm{mg}$ RTV twice daily. Combination ART(adults):

- Co-administration with EFV requires $800 \mathrm{mg}$ IDV plus 100 or $200 \mathrm{mg}$ RTV twice daily.

\begin{tabular}{|c|c|}
\hline $\begin{array}{l}\text { Lopinavir/ritonavir } \\
\text { (LPV/RTV, } \\
\text { Kaletra, } \\
\text { ABT 378) }\end{array}$ & $\begin{array}{l}\text { Body weight } 14-39.9 \mathrm{~kg}-10 \mathrm{mg} \mathrm{LPV} / \mathrm{kg} / \\
\text { dose } \\
\text { twice daily (equivalent to } 300 \mathrm{LPV} \mathrm{mg} / \mathrm{m}^{2} \text { ). } \\
\text { Body } \\
\text { weight } 15-40 \mathrm{~kg}-2.5 \mathrm{mg} \mathrm{RTV} / \mathrm{kg} / \mathrm{dose} \\
\text { twice daily } \\
\text { (equivalent to } 75 \mathrm{mg} / \mathrm{m}^{2} \text { ). Maximal dose- } \\
400 \mathrm{mg} \\
\mathrm{LPV} \text { plus } 100 \mathrm{mf} \mathrm{RTV} \text { twice daily. } \\
\text { Adults/combination ART—capsules ( } 133.3 \\
\mathrm{mg} \\
\mathrm{LPV} / 33.3 \mathrm{mg} \mathrm{RTV}) 3 \text { capsules twice daily } \\
\text { or } 4 \\
\text { capsules twice daily when co-administered } \\
\text { with } \\
\text { EFV ( } 600 \mathrm{mg} \text { once daily) or NVP ( } 150 \mathrm{mg} \\
\text { twice daily); } \\
\text { tablets ( } 200 \mathrm{mg} \text { LPV/100 mg RTV) for } \\
\text { treatment- } \\
\text { naive patients - } 2 \text { tablets twice daily, for } \\
\text { treatment- } \\
\text { experienced patients - } 3 \text { tablets twice daily } \\
\text { when } \\
\text { co-administered with EFV ( } 600 \mathrm{mg} \text { once } \\
\text { daily) or NVP } \\
\text { (150 mg twice daily). }\end{array}$ \\
\hline
\end{tabular}

Pediatric: body weight $>15-<40 \mathrm{~kg}-10 \mathrm{mg} / \mathrm{kg} \mathrm{LPV} / 2.5 \mathrm{mg} / \mathrm{kg} \mathrm{RTV}$ twice

daily with food. Approximately equivalent to $230 \mathrm{mg} / \mathrm{m}^{2} \mathrm{LPV} / 57.5 \mathrm{mg} /$ $\mathrm{m}^{2}$

RTV per dose. Body weight $>40 \mathrm{~kg} — 400 \mathrm{mg}$ or $230 \mathrm{mg} / \mathrm{m}^{2} \mathrm{LPV} / 57.5$ $\mathrm{mg} / \mathrm{m}^{2}$

RTV per dose (maximal dose, $400 \mathrm{mg}$ LPV/100 mg RTV). Use of 230 $\mathrm{mg} / \mathrm{m}^{2}$

LPV dose provides adequate AUC for LPV, but might produce lower trough,

higher doses may be considered.

Adolescent >12 years: $400 \mathrm{mg}$ LPV/100 mg RTV per dose twice daily with food.

Adolescent $>18$ years/adults: in antiretroviral naive patients $-800 \mathrm{mg}$ LPV/200 mg RTV per dose once daily.

Combination ART (adolescents >12 years/adults):

- Once daily dose should not be used in patients with concomitant therapy with EFV, NVP, f-AMP or NFV.

- Co-administration with NVP, EFV or f-AMP requires increase in LPV/RTV dose to $300 \mathrm{mg} / \mathrm{m}^{2} \mathrm{LPV} / 75 \mathrm{mg} / \mathrm{m}^{2}$ RTV per dose in children < 12 years of age and $600 \mathrm{mg} \mathrm{LPV/}$ $150 \mathrm{mg}$ RTV per dose twice daily with food. Combination ART (adults):

- Co-administration with SQV requires $1,000 \mathrm{mg} \mathrm{SQV}$ dose without additional RTV twice daily with twice daily $400 \mathrm{mg}$ LPV/100 mg RTV.

- Co-administration with MVC requires $150 \mathrm{mg}$ MVC dose with $400 \mathrm{mg} \mathrm{LPV} / 100 \mathrm{mg}$ RTV, all twice daily.

\begin{tabular}{|c|c|c|}
\hline $\begin{array}{l}\text { Nelfinavir } \\
\left(\mathrm{NFV}, \text { Viracept }{ }^{\circledR}\right)\end{array}$ & $\begin{array}{l}\text { Body weight } \geq 20 \mathrm{~kg}-\text { maximum } \\
\text { recommended dose } \\
\text { of } 1,250 \mathrm{mg} / \text { dose twice daily. } \\
\text { Adults }-1,250 \mathrm{mg} / \text { dose twice daily. }\end{array}$ & $\begin{array}{l}\text { Pediatric }<13 \text { years: } 45-55 \mathrm{mg} / \mathrm{kg} / \mathrm{dose} \text { twice daily or } 25-35 \mathrm{mg} / \mathrm{kg} / \mathrm{dose} \\
\text { three times daily. } \\
\text { Adolescent/adults: } 1,250 \mathrm{mg} / \mathrm{dose} \text { twice daily or } 750 \mathrm{mg} / \text { dose three } \\
\text { times daily. }\end{array}$ \\
\hline $\begin{array}{l}\text { Ritonavir } \\
\text { (RTV, Norvir }^{\circledR} \text { ) }\end{array}$ & $\begin{array}{l}\text { Children }<16 \text { years }-400 \mathrm{mg} / \mathrm{m}^{2} / \text { dose } \\
\text { (maximal dose, } \\
600 \mathrm{mg} \text { ) twice daily. Scale up the dosing } \\
\text { schedule at } \\
\text { initiation starting at } 250 \mathrm{mg} / \mathrm{m}^{2} / \mathrm{dose} \text { of } \\
\text { body surface } \\
\text { area twice daily with increments by } 50 \mathrm{mg} / \\
\mathrm{m}^{2} / \text { dose at } \\
\text { 2- to 3-day intervals to full dose as } \\
\text { tolerated. } \\
\text { As a booster for LPV for body weight }\end{array}$ & $\begin{array}{l}\text { Pediatric: } 350-450 \mathrm{mg} / \mathrm{m}^{2} / \text { dose (maximal dose, } 600 \mathrm{mg} \text { ) twice daily. } \\
\text { Scale } \\
\text { up the dosing schedule at initiation starting at } 250 \mathrm{mg} / \mathrm{m}^{2} / \text { dose twice daily } \\
\text { with increments by } 50 \mathrm{mg} / \mathrm{m}^{2} \text { at } 2 \text { - to } 3 \text {-day intervals to full dose as } \\
\text { tolerated. } \\
\text { Adolescent/adults: } 600 \mathrm{mg} / \mathrm{dose} \text { twice daily. Scale up the dosing schedule } \\
\text { at initiation starting at } 300 \mathrm{mg} / \text { dose twice daily; and in stepwise increase } \\
\text { until full dose is reached over } 5 \text { days as tolerated. } \\
\text { Combination ART (adolescents/adults): }\end{array}$ \\
\hline
\end{tabular}

Clin Pharmacol Ther. Author manuscript; available in PMC 2010 January 7. 


\begin{tabular}{|c|c|c|}
\hline Drug & WHO guidelines & US guidelines \\
\hline & $\begin{array}{l}15-40 \mathrm{~kg}-2.5 \mathrm{mg} / \mathrm{kg} / \text { dose twice daily. No } \\
\text { dosing } \\
\text { guidelines for adults. }\end{array}$ & $\begin{array}{l}\text { - RTV is used at lower doses as a pharmacokinetic enhancer to } \\
\text { other PIs with doses ranging from } 100 \text { to } 400 \mathrm{mg} \text {. }\end{array}$ \\
\hline \multirow[t]{3}{*}{$\begin{array}{l}\text { Saquinavir } \\
\left(\mathrm{SQV}, \text { Invirase }{ }^{\circledR}\right)\end{array}$} & $\begin{array}{l}\text { Not licensed for use in children < } 16 \text { years } \\
\text { of age or less } \\
\text { than } 25 \mathrm{~kg} \text {. } \\
\text { Never should be taken unboosted. } \\
\text { Adults-1,000 mg SQV plus } 100 \mathrm{mg} \text { RTV } \\
\text { twice daily. }\end{array}$ & $\begin{array}{l}\text { Pediatric: Not approved for use in children. Investigational dose of } \\
50 \mathrm{mg} / \mathrm{kg} / \text { dose every } 8 \text { hours (three times daily) provided inadequate } \\
\text { AUC and plasma trough. Co-administration with RTV, LPV/RTV and } \\
\text { NFV } \\
\text { is being investigated. } \\
\text { Adolescent }>16 \text { years/adults: } 1,000 \mathrm{mg} \text { plus } 100 \mathrm{mg} \text { RTV twice daily. } \\
\text { Never should be used unboosted. } \\
\text { Combination ART (adults): }\end{array}$ \\
\hline & & $\begin{array}{l}\text { - Co-administration with LPV/RTV requires } 1,000 \mathrm{mg} \mathrm{SQV} \\
\text { dose without additional RTV twice daily with twice daily } 400 \\
\mathrm{mg} \text { LPV/100 mg RTV. }\end{array}$ \\
\hline & & $\begin{array}{l}\text { Co-administration with MVC requires } 150 \mathrm{mg} \text { MVC dose } \\
\text { with } 1,000 \mathrm{mg} \text { SQV plus } 100 \mathrm{mg} \text { RTV, all twice daily. }\end{array}$ \\
\hline
\end{tabular}

\begin{tabular}{ll}
\hline Tipranavir & No dosing guidelines for children. \\
(TPV , Aptivus ${ }^{\circledR}$ ) & No dosing guidelines for adults.
\end{tabular}

Pediatric: Not approved for use in children. Currently under study in (TPV, Aptivus ${ }^{\circledR}$ ) No dosing guidelines for adults. PACTG1051/BI1182.14.

Adult dose $^{d}: 500 \mathrm{mg}$ plus $200 \mathrm{mg}$ RTV twice daily. Combination ART (adults):

- Co-administration with MVC requires $300 \mathrm{mg}$ MVC dose with $500 \mathrm{mg}$ TPV plus $200 \mathrm{mg}$ RTV, all twice daily.

\begin{tabular}{|c|c|}
\hline $\begin{array}{l}\text { Maraviroc } \\
\left(\text { MVC, Selzentry }{ }^{\circledR}\right)\end{array}$ & $\begin{array}{l}\text { No dosing guidelines for children. } \\
\text { No dosing guidelines for adults. }\end{array}$ \\
\hline
\end{tabular}

Pediatric: Not approved for use in children < 16 years. No data currently available on dosage below this age.

Combination ART (adolescents/adults): When given with CYP3A4 inhibitors

(with or without CYP3A4 inducers) including all PIs (except TPV/RTV)

$-150 \mathrm{mg} /$

dose twice daily. When given with other drugs that are not strong inhibitors

or inducers of CYP3A4, such as NRTIs, T-20, TPV/RTV, and NVP-300

$\mathrm{mg} / \mathrm{dose}$

twice daily. When given with CYP3A4 inducers including EFV-600

$\mathrm{mg} / \mathrm{dose}$

twice daily. ${ }^{e}$

\begin{tabular}{lll}
\hline $\begin{array}{l}\text { Enfuvirtide } \\
\left.\text { (Fuzeon }{ }^{\mathrm{TM}}, \mathrm{T}-20\right)\end{array}$ & $\begin{array}{l}\text { No dosing guidelines for children. } \\
\text { No dosing guidelines for adults. }\end{array}$ & $\begin{array}{l}\text { Pediatric: } 2 \mathrm{mg} / \mathrm{kg} \text { (maximal dose, } 90 \mathrm{mg}[1 \mathrm{ml}]) \mathrm{twice} \text { daily injected } \\
\text { subcutaneously into the upper arm, anterior thigh, or abdomen. } \\
\text { Fusion Inhibitor }\end{array}$
\end{tabular}

The recommended doses are taken verbatim from the public-domain guidelines available at

http://www.who.int/hiv/pub/guidelines/art/en/index.html and http://aidsinfo.nih.gov/Guidelines, respectively.

ART, antiretroviral therapy; AUC, area under the curve; CYP3A4, cytochrome P450 3A4; IMPAACT, International Maternal Pediatric Adolescent AIDS Clinical Trials; PACTG, Pediatric AIDS Clinical Trials Group; PI, protease inhibitor; PK, pharmacokinetic; WHO, World Health Organization.

a Both weight and age are used to define "adolescent" patient. In certain references neither is used and "adolescent" is referred to as a category.

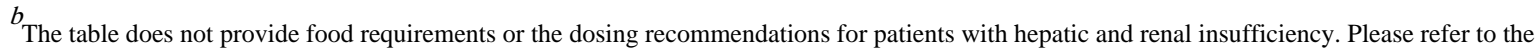
actual guidelines available online at: http://www.who.int/hiv/pub/guidelines/art/en/index.html and http://aidsinfo.nih.gov/Guidelines.

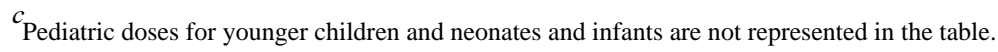

${ }^{d}$ No adolescent dose is referenced in the guidelines. 


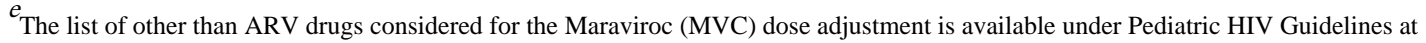
http://aidsinfo.nih.gov/Guidelines. 